\title{
Biochemical factors contributing to tomato fruit sugar content: a review
}

\author{
Diane M. BeCKLeS ${ }^{1 *}$, Nyan Hong ${ }^{1}$, Liliana StAmova ${ }^{2}$, Kietsuda LuengWILA1 ${ }^{1,3}$
}

\author{
${ }^{1}$ Dep. Plant Sci., Univ. Calif., \\ One Shields Ave., Davis, \\ CA 95616, USA, \\ dmbeckles@ucdavis.edu \\ 21632 Santa Rosa St., Davis, \\ CA 95616, USA \\ ${ }^{3}$ Current address: \\ Dep. Hortic., Fac. Agric. \\ Kamphaeng Saen, Kasetsart \\ Univ., Kamphaeng Saen \\ Campus Kamphaeng Saen \\ Nakhon Pathom, 73140, \\ Thailand
}

\begin{abstract}
Biochemical factors contributing to tomato fruit sugar content: a review
Abstract - Introduction. Consumers and processors value tomatoes with high fruit sugar content; however, most breeding and cultural practices negatively impact this trait. Wild tomato species can accumulate two- to three-fold more fruit sugar than cultivars and are proving to be valuable both as a source of high-sugar loci to broaden the genetic base of currently produced cultivars, and as research material to understand this trait. Synthesis. While cutting-edge genomic approaches have taught us much about fruit phenotypes, it is still important to assess fruit enzyme activities and metabolic fluxes in lines with contrasting fruit sugar accumulation. These metabolic functions are closest to the ripe fruit sugar trait. In this review, we focus our attention on the biochemical pathways, especially starch biosynthesis, that may influence tomato fruit sugars. We try where possible to put this information into a physiological context because together they influence yield. We compare and contrast sugar metabolism in cultivars and wild tomato species and identify factors that may influence differences in their fruit size. Conclusion. Although difficult, we show that it is possible to develop fruit with high horticultural yield and use the breeding line 'Solara' as an example. In addition, we suggest avenues of further investigation to understand the regulation and control of fruit carbohydrate content.
\end{abstract}

USA / Solanum lycopersicum / fruits / sugars / carbohydrate metabolism / carbohydrate content

\section{Facteurs biochimiques contribuant à la teneur en sucre des fruits de tomate : une revue.}

Résumé — Introduction. Les consommateurs et les industriels apprécient les tomates avec un fort taux en sucres, mais la plupart des pratiques culturales et d'amélioration ont un impact négatif sur ce caractère. Les espèces de tomate sauvage peuvent accumuler 2 ou 3 fois plus de sucres dans le fruit que des cultivars et elles s'avèrent précieuses à la fois comme une source de loci à haute teneur en sucres pour élargir la base génétique des cultivars actuellement produits, et comme matériel de recherche pour comprendre ce caractère. Synthèse. Alors que les approches génomiques de pointe nous ont appris beaucoup sur le phénotype des fruits, il reste important d'évaluer l'activité des enzymes de fruits et les flux métaboliques dans des lignées présentant des situations contrastées d'accumulation de sucres dans les fruits. Ces fonctions métaboliques sont les plus proches du caractère de teneur en sucres dans le fruit mûr. Dans cette synthèse, nous nous sommes focalisés sur les voies biochimiques, en particulier sur la biosynthèse de l'amidon qui peut influencer les sucres dans le fruit des tomates. Nous essayons autant que possible de mettre cette information dans un contexte physiologique car, ensemble, ils influencent le rendement. Nous comparons et mettons en contraste le métabolisme des sucres dans les cultivars et les espèces sauvages de tomate et nous identifions les facteurs qui peuvent influencer des différences de taille des fruits. Conclusion. Bien que cela soit difficile, nous montrons qu'il est possible de produire des fruits présentant un rendement horticole élevé et nous utilisons la lignée sélectionnée "Solara " comme exemple. En outre, nous suggérons des pistes de recherches supplémentaires pour comprendre la régulation et le contrôle du contenu en glucides des fruits.

États-Unis / Solanum lycopersicum / fruits / sucres / métabolisme des glucides / teneur en glucides
Fruits, 2012, vol. 67, p. 49-64 (C) 2012 Cirad/EDP Sciences All rights reserved DOI: 10.1051/fruits/2011066 www.fruits-journal.org

RESUMEN ESPAÑOL, p. 64 


\section{Introduction}

The tomato is one of the most popular fruits, with global production estimated at $\sim 1.26 \mathrm{Mt}$ per year ${ }^{1}$. Tomato fruits are an excellent source of vitamins A, C, E and lycopene, which collectively may lower the risk and occurrence of some cancers [1-3] and heart disease [4-6]. Both fresh and processed tomatoes are widely used in many traditional and modern dishes and the zeal for a 'perfect-tasting' tomato has spurred sociopolitical advocacy for local, sustainable, organic production of heirloom varieties [7].

Figure 1.

Changes in fruit physiology and carbohydrate accumulation from anthesis to full maturity. Tomato classification as Immature, Mature Green, Breaker, Pink and Red Ripe are based on USDA Standards [95]. DPA are approximate and based primarily on a composite of data from S. lycopersicum L. cv. Moneymaker as described in Kortsee et al. [58], Luengwilai and Beckles [30], and Carrari et al. [105], and from other cultivars as described in Gillapsy et al. [14] and Schaffer and Petreikov [106]. Note starch synthesis is distinct from accumulation.

One key component of fruit quality is total soluble solids (TSS). Although TSS of ripe tomato fruit is a measurement of several chemicals, it is a convenient proxy for sugar content [8]. Higher TSS positively influences consumer fruit likeability and reduces costs associated with processing tomatoes [8].

The problem is that fruit are bred for optimal postharvest handling [8] but, even when trying to genetically select for fruit with higher total soluble solids, a loss of yield occurs [9]. Exacerbating this problem is that commercial harvesting is usually done before the fruit reaches full-ripe and this cuts off the sugar supply from the fruit, leading to a less than favourable content [8]. One solution to this problem is to develop higher

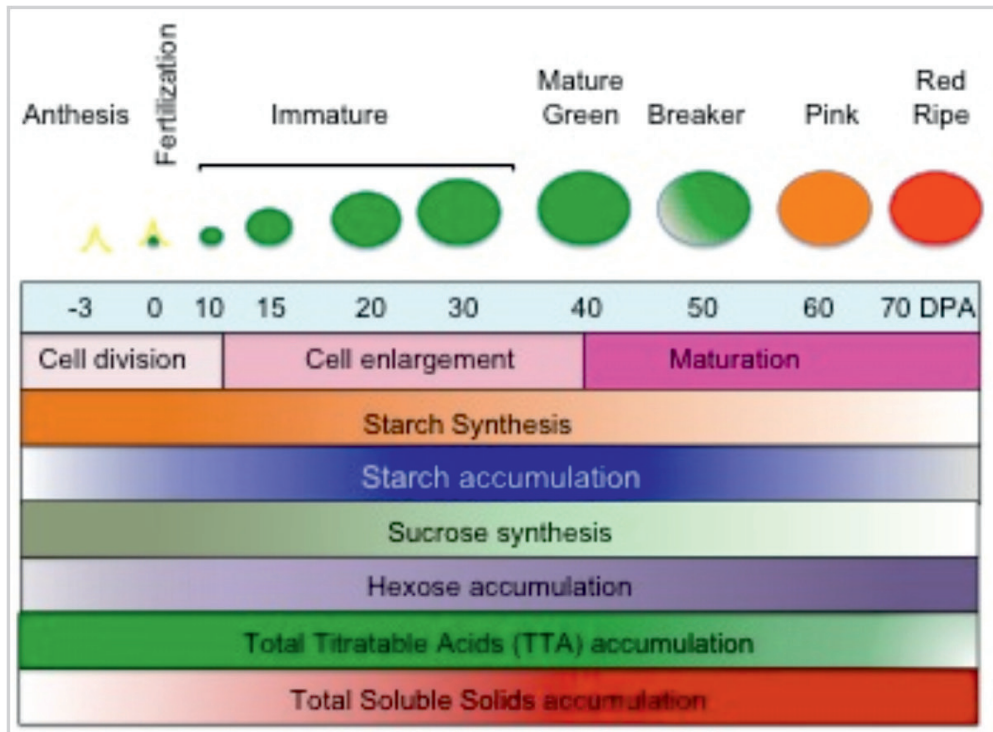

${ }^{1}$ FAOSTAT, FAO, 2006.
TSS 'value-added' fruit to offset any loss of yield and to minimise the severity of the effect on sugars by premature harvesting. In our review we will look at the biochemical factors that help to determine the potential for high sugar accumulation.

\section{Tomato fruit development}

Fruit development from anthesis to full maturation is regulated by changes in endogenous and external environmental signals whose perception is relayed by hormonal and sugar signalling [10-13]. There are five recognisable phases [14]: anthesis, fertilisation, cell division, cell expansion and ripening, with some overlap between stages. Cell division occurs in the newly-formed fruit for 7-10 days [15], or in large-fruited cultivars for 20 days [16], after which the final fruit cell number is set. The cells then expand from 10-40 days post-anthesis (DPA) due to the vacuolar storage of photosynthate and water, leading to a more than ten-fold increase in fruit size [14, 17]. The final stage is ripening, in which the fruit undergoes several metabolic transformations brought on by climacteric ethylene, including the rapid import and accumulation of sugars, degradation of starch and synthesis of lycopene and carotenoids, the degradation of chlorophyll and the softening of the cell wall [18].

Tomato yield relies partly on cell division and partly on cell enlargement, events that occur in the green developing fruit, while fruit quality parameters are determined during ripening, especially after the climacteric period (figure 1). Early events influencing cell number and hence yield include [14] endoreduplication [19, 20], seed number [21] and hormone production, especially in seeds [17, 22-25]. The number of cells can then subsequently influence sink strength, i.e., import of photosynthate from the source [26].

\section{Carbohydrate metabolism in developing fruit}

The carbon economy of the fruit changes as the organ matures. Sucrose is the major 
photoassimilate translocated to the fruit. The movement of this photoassimilate from source to sink occurs in the phloem, and is in response to a pressure gradient developed from differences in the osmotic potential at the site of phloem loading in the source, and at the site of unloading at the sink. Sucrose is transported to fruit cells via the symplast (through the plasmodesmata) or it may be metabolised in the apoplast by a cell wall invertase and the resulting hexoses imported via hexose transporters on the plasma membrane (figure 2). For several years the accepted view was that symplastic loading of sucrose predominated in young fruit while apoplastic loading of hexose occurred principally during ripening [27] however, this paradigm has been questioned recently and the possibility that apoplastic loading may occur throughout fruit development has been suggested [25]. Sucrose in the cytoplasm is metabolised into UDPglucose and fructose by sucrose synthase (Susy) or into fructose and glucose by the neutral cytoplasmic invertase (figure 2). The activity of Susy, along with the hexokinases, may mobilise carbon from sucrose for the hexose phosphate pool, while sucrose metabolised by invertases may be destined for storage in the vacuole $[27,28]$, requiring active transport into that organelle [29]. Biochemical and molecular evidence suggests that both Susy and invertase activities are determinants of fruit sink strength [25].

In green fruit, hexose phosphates are mostly used for the synthesis of starch, which occurs rapidly from anthesis until 13 days post-anthesis (DPA) [30, 31] (figures 1, 2). This period also coincides with high levels of mitotic activity and the determination of the final cell number in the fruit $[14,32]$. Fixing these newly imported sugars as starch may steepen the sugar gradient to the fruit and aid continued sugar import [30, 33-35]. On a per fruit basis, starch reaches maximal accumulation at $\sim 40$ DPA and is thereafter degraded in concert with ripening [30].

The starch and sucrose pools are turned over in tomato fruit. Sucrose re-synthesis may occur via Sucrose Phosphate Synthase (SPS) and Susy, and the activity of these enzymes remains relatively high during fruit

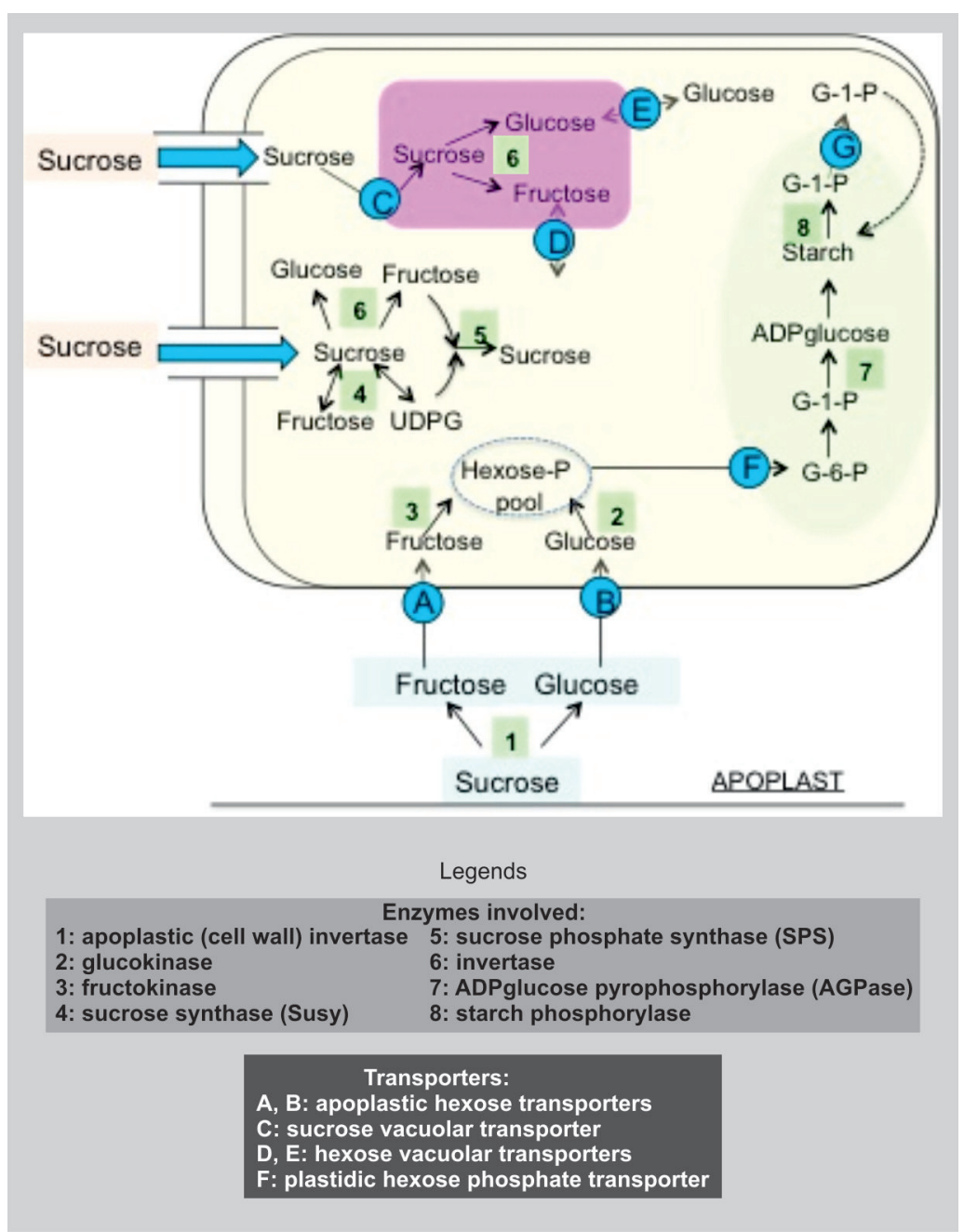

Figure 2.

Carbohydrate metabolism in developing tomato fruit. Sucrose may be imported directly via the symplast or may be inverted in the apoplast to hexoses which are then imported into the cell. Both sucrose and hexoses may be stored in the vacuole. The flux of sucrose to starch occurs early in fruit development from anthesis to 2025 days post-anthesis (DPA). Here, sucrose metabolism via sucrose synthase and hexokinases dominates. Hexose phosphate intermediates are then imported into the plastid for the synthesis of starch. As the fruit ripens, Susy and hexokinase activity declines relative to invertase and the apoplastic import of hexose becomes more significant with storage of sugars in the vacuole. Starch biosynthesis is minimal and active degradation of the starch occurs, which may add to the sugar content available for storage.

development [28, 36]. The enzyme isoforms involved in the disassembly of starch during turnover are not known [27, 37]. Enzymes capable of degrading starch via amylolytic routes have been detected in the plastids of 


\section{Table I.}

Sources of high soluble solids traits in wild tomato species.

\begin{tabular}{|c|c|c|c|c|c|}
\hline $\begin{array}{l}\text { Wild species of } \\
\text { Solanum }\end{array}$ & $\begin{array}{l}\text { Fruit } \\
\text { colour }\end{array}$ & Locus & $\begin{array}{c}\text { Primary storage } \\
\text { sugar(s) }\end{array}$ & Mechanism reported ${ }^{1}$ & Reference \\
\hline S. cheesmanii & yellow & - & fructose, glucose & Increased sugar import during ripening & Balibrea et al. [45] \\
\hline S. pimpinellifolium & red & - & fructose, glucose & Increased invertase activity & Husain et al. [52, 53] \\
\hline S. pennelli & green & Lin5 & fructose, glucose & Apoplastic invertase with altered activity & Fridman et al. [50] \\
\hline S. chmielewskii & green & sucr & sucrose & Reduced fruit acid invertase activity & Chetelat et al. [96] \\
\hline S. habrochaites & green & Agp-L1 & sucrose & $\mathrm{Agp}^{2}$ and increased fruit starch & Petreikov et al. [33] \\
\hline S. habrochaites & green & fgr, frk & $\begin{array}{c}\text { higher } \\
\text { fructose:glucose }\end{array}$ & Epistatic interaction between $f r k^{3}$ and $f g r$ & Levin et al. [97] \\
\hline S. neorickii & green & - & sucrose & Unknown & Schauer et al. [56] \\
\hline S. peruvianum & green & - & sucrose & Higher sucrose import during ripening & Stommel [49] \\
\hline
\end{tabular}

${ }^{1}$ This does not imply that the biochemical difference is the sole cause for changes in total soluble solids.

${ }^{2}$ Agp is ADPglucose pyrophosphorylase.

${ }^{3}$ Frk is fructokinase.

developing tomato fruit as early as 10 DPA, but they have not yet been shown to be directly involved in starch breakdown [38, 39]. Substrate cycles of sucrose and starch may provide metabolic flexibility and help to maintain the fruit as a carbon sink [30].

\section{Carbohydrate pathways in wild tomato fruit}

It is perhaps ironic that one of the traits most sought after during the domestication of tomato was increased yield [40], which coincidentally led to lower fruit TSS [21]. However, genetic, molecular and biochemical characterisation of wild tomato species with high fruit TSS (10-15\% compared with 4-6\% in cultivars) have vastly improved our understanding of carbohydrate metabolism in tomato, and can be exploited in breeding programmes [41]. Even among landraces of Solanum lycopersicum L. there is a great deal of underutilised potential for new sources of high TSS [42-44].

Differences exist in the pathway steps (figure 2) that partially explain the distinct sugar profiles of wild and modern tomatoes (table I). No single mechanism universally explains increased TSS across all of the species examined. However, in addition to metabolic alterations, increased import of sugars, especially during the later stages of fruit development, has been identified in S. cheesmanii [45], S. chmielewskii [35, 46] S. pennellii [47], S. habrochaites [48], S. peruvianum [49] and S. pimpinellifolium as a contributory factor [45]. And although some "key" enzymes vary several-fold in activity between cultivars and the wild relatives, there may also be subtle but widespread variation in many fruit enzyme activities throughout development [28].

Two biochemical modifications related to differences in sugar import during fruit development in wild tomato species have been identified; changes in invertase activity and changes in starch accumulation. The magnitude and direction of the changes vary from species to species.

Solanum chmielewskii, S. peruvianum, $S$. neorickii and $S$. habrochaites are sucrosestorers. All except $S$. neorickii (where it has not been studied) contain invertases less adept at converting sucrose into hexoses, which leads to high accumulation of the former during late fruit development [25, 35, 
$46,50]$. Rapid rates of sucrose recycling may also accelerate sucrose import in $S$. habrochaites [27]. Miron et al. found, in addition to lower invertase, higher activity of Susy and SPS. They proposed that this could amplify the sucrose gradient to fruit; sucrose would be metabolised by Susy in the cytosol with subsequent re-synthesis by SPS and import into the vacuole at greater rates than in the cultivar [48]. This is an attractive hypothesis and comports well with the idea that sucrose is turned over in fruit and with the higher SPS activity found in another sucrose-storer, $S$. peruvianum. However, in S. chmielewskii SPS and Susy activities similar to domesticated tomatoes were measured [51], suggesting that higher sucrose cycling may not occur in all sucrose-storers. There are no reports of these enzyme activities in S. neorickii.

In contrast to the sucrose-accumulating species, S. cheesmanii [45], S. pennellii [47, 50] and $S$. pimpinellifolium [52] store large amounts of glucose and fructose that may be conditioned by higher invertase activity compared with the cutivars. Solanum pennellii has been extensively studied. High apoplastic invertase activity was found in the columella which increased during ripening. This activity would magnify the sucrose gradient between the phloem and fruit parenchymal cells by the rapid inversion of sucrose to hexose $[52,53]$. A similar mechanism may operate in S. pimpinellifolium in the apoplast to aid sink strength, but there must be other factors contributing to high TSS in this species. About 90\% of the invertase activity in this species is vacuolar, not apoplastic, and vacuolar activity correlated with the linear accumulation of hexose during ripening [52, 53]. The situation is even less clear for $S$. cheesmanii. Only the cytosolic invertase activity was higher, and slightly so, when compared with the cultivar, and only at 20 DPA when sugar import for storage is minimal [45]. Also of note is that although $S$. habrochaites stores sucrose, it has a higher ratio of fructose to glucose. This is due to the presence of the frg allele and its epistatic interaction with fructokinase $[54,55]$. This is desirable because fructose, along with sucrose, is sweeter than glucose [8], and attempts to engineer high fructose by changing fructokinase activity have been unsuccessful.

Many high-TSS wild tomatoes also show alterations in starch metabolism. Solanum chmielewskii [56], S. pennellii [28, 47] and $S$. habrochaites (formerly Lycopersicon hirsutum) [57] accumulate more starch, while $S$. peruvianum accumulates less starch at some stages [58] compared with $S$. lycopersicum. The mechanism by which altered starch accumulates in some wild species is not widely known except for $S$. habrochaites. This species harbours a modified allele of the large subunit of ADPglucose pyrophosphorylase (AGPase; figure 2) which is a key enzyme of starch biosynthesis. The $S$. habrochaites AGPase remains active for an extended period, leading to higher levels of starch biosynthesis in the fruit [33, 58]. Petreikov et al. proposed that this modification simultaneously enhances sink capacity, thereby leading to higher sugar accumulation, and the 'extra' starch adds more sugars to the final reserves in ripe fruit $[33,59]$. It may not be surprising that some 'sucrosestorers' would synthesise more starch since it has been posited that the amount of starch synthesised in fruit is driven by sucrose content [27, 37]. Schauer et al. also suggested that since many of these fruit remain green, photosynthetic activity may also contribute to starch [56].

Finally, a major caveat in making crosscomparisons of fruit metabolism between studies as we have done is the potential for drawing inaccurate conclusions. For example, Solanum chmielewskii was shown to accumulate more starch than the cultivar [56] but there are two reports that this species accumulates less starch [35, 45]. And, peculiarly, Solanum cheesmanii does not have the large increase in invertase activity expected of high-TSS hexose-storers. These observed disparities could be due to a number of reasons: (i) variation in the fruit tissues sampled, i.e., pericarp vs. columella vs. whole fruit. Baxter et al. found higher uptake of sugars in the columella but not in the pericarp of $S$. pennellii, pointing to the importance of enzyme tissue specificity [47]. Therefore, the modest levels of invertase activity found in $S$. cheesmanii may be a result of sampling only the pericarp and not 
the columella; (ii) variation in fruit maturation at the time of sampling due to developmental shifts between wild tomatoes and cultivars [28], and (iii) differences in the accessions sampled. For example, some accessions of S.pimpinellifolium have invertase activity similar to cultivars [52].

\section{Fruit size and yield in wild tomato fruit}

Wild tomato species that produce fruit with high TSS content are low-yielding, while the inverse is true for cultivars. This link will be important to break if the tomato industry wishes to meet its goal of increasing TSS in large-fruited cultivars. Three mechanisms can be put forth to explain this. First, in large-fruited cultivars there could be "dilution effects" [45, 60]. Hexoses have a higher osmolarity compared with sucrose which would lead to a greater influx of water to the cells and, consequently, larger cell volumes and fruit sizes [46]. Second, sequence polymorphisms in the fw2.2 allele can account for $30 \%$ of the difference in fruit size between wild species and cultivars by altering cell division in the pre-anthesis ovary [40]. Third, the relative proportion of hexose to sucrose in fruit may differ between wild and cultivated types during cell division, directly affecting this process. In Arabidopsis and legume seeds a high hexose-tosucrose ratio at cell division stimulates mitotic activity, leading to more cells and a larger organ [61-63]. If this phenomenon is universal then it may be part of the reason for differences in fruit size among tomato species. When the fruit sugar profiles of S. lycopersicum were compared with those of the small-fruited S. chmielewskii [46], $S$. habrochaites and $S$. peruvianum [58], the hexose-to-sucrose ratio during cell division was significantly higher in the former, suggesting that this could contribute to the differences in fruit size between these two species. This thesis requires further testing on a broader spectrum of tomato species. Also interesting would be to establish if fw2.2, which is regulated by sugars [10], shows a differential response to hexose $v s$. sucrose.

\section{Developing tomato lines with high total soluble solids content and good yield - Solara: A case study}

Fruit with modest increases in TSS but with no yield penalty have been produced through crosses involving S. chmielewskii [64] and S. pennellii [65] (TSS increases of $10-12 \%$ and $6 \%$, respectively) and, more recently, yield increases were introduced into a tomato variety with no concomitant change in TSS [66]. However, engineering high horticultural yield is difficult due to the constraints imposed by source-sink relations. We studied 'Solara', a breeding line with fruit that are twenty-fold larger than those of S. pimpinellifolium L., from which it was derived, and yet are high in TSS (9$11 \%$ ), and that appears to be an exception to this general rule [67].

'Solara' was derived by crossing a Bulgarian cultivar (Solanum lycopersicum L.) and S. pimpinellifolium L., followed by 10 years of selections among the segregating population. In the experiment described (table II), 'Solara' had a 30\% higher horticultural yield compared with Solanum lycopersicum L. cv. Moneymaker. The fruit have high TSS from 9-11\% (table II), lower than that of cherry tomato hybrids (10-15\%) and the S. pimpinellifolium parent (12\%; [68, 69]), but higher than most table or processing varieties (4-6\%; [35]). In addition, summer fieldgrown 'Solara' fruits' TSS approaches 10$13 \%$ (L. Stamova, unpubl. data) in multiple tests. 'Solara' fruits' Total Sweetness Index (TSI) of $6.7 \pm 0.2$ (table II) is higher than the normal range of 3.8 to 5.0 reported for fresh market tomato varieties, indicating an exceptionally sweet fruit [70]. The fruit has 2-3 locules and a low proportion of gelatinous tissue which may further contribute to its high [TSS / TA] ratio [71]. When grown under suboptimal conditions (Winter, table II), 'Solara' fruits' TSS were unchanged (9\%), suggesting a strong genetic basis for this trait. 


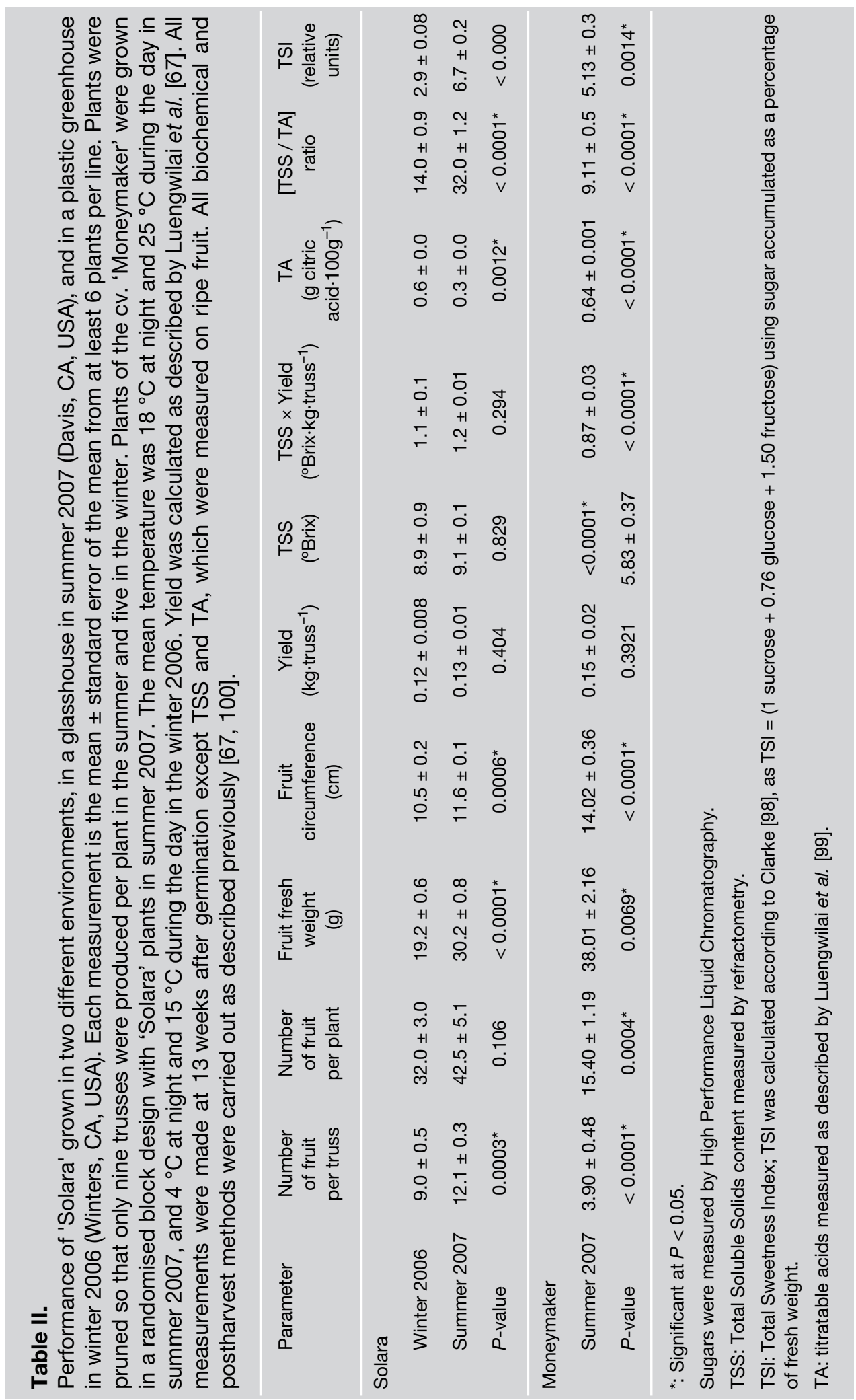


Table III.

Role of carbohydrate genes in tomato fruit derived from transgenic manipulation.

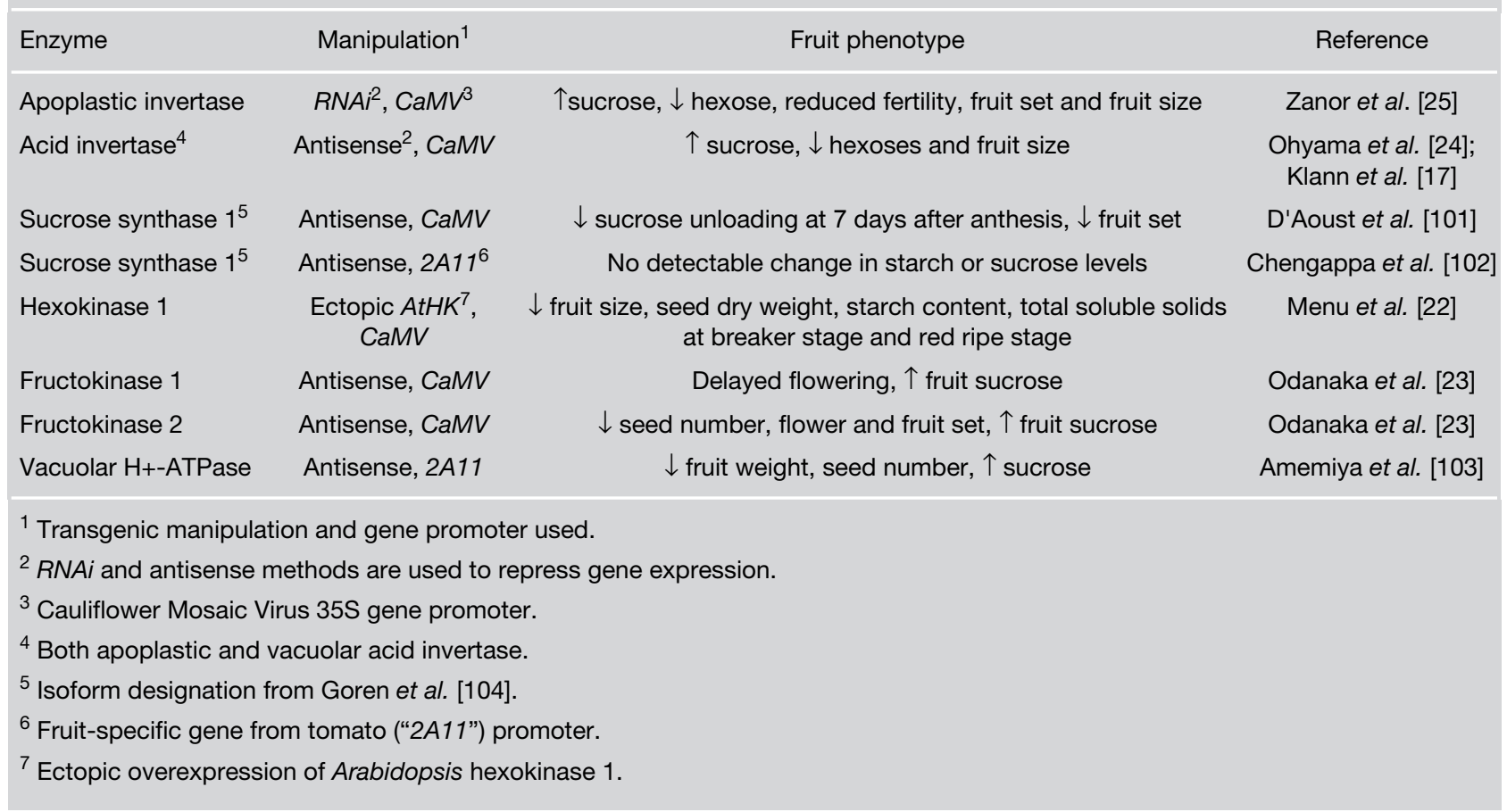

Biochemical and physiological analysis of 'Solara' points to high import of sugars (primarily glucose and fructose) over a longer period compared with Moneymaker [67]. Sucrose is synthesised at high rates but accumulation, while higher than in Moneymaker, does not match synthesis, indicating higher rates of cycling [67]. Starch turnover at the red ripe phase was detected in 'Solara' but not in Moneymaker by ${ }^{14} \mathrm{C}$-glucose pulse-chase experiments (unpubl. data).

\section{Understanding the role of fruit metabolism in determining fruit sugar content}

There are several basic questions regarding tomato fruit carbohydrate metabolism that remain unanswered. Transgenic alterations, and repression or overexpression of various genes have provided some valuable infor- mation on the roles of various enzymes in fruit metabolism (table III; [72]). We agree with others that knowledge of metabolic fluxes and enzyme activity will be important in putting the puzzle together, and that this cannot be overstated [28, 73, 74]. There are areas 'ripe' for investigation into tomato fruit carbon fluxes that we still need to understand.

1. Susy, SPS and AGPase [27] are highly regulated enzymes that may be constrained by regulatory loops [73, 75]. Expression of enzymes modified by site-directed mutagenesis may promote increased flux through the pathway at these points. For instance, changes in the activation state of AGPase lead to more starch and higher TSS (see point 7).

2. Many fruit enzymes involved in carbohydrate metabolism have multiple isoforms, each with unique kinetic properties and restricted spatio-temporal occurrence (e.g., invertases, Susy, fructokinase). Sequential and combinatorial "knocking out" of the 
various isoforms as demonstrated by Barratt et al. [76] would contribute to our basic knowledge of their unique and shared contributions to total enzymatic activity.

3. Membrane transporters are the gateways for the movement of metabolites and compounds between compartments [77] and they can have all-encompassing effects on fluxes. But the roles of several of these transporters remain under-studied in tomato fruit (figure 2). There is now evidence for the regulation of plant sugar transporters by endogenous sugar levels via kinases [78] which adds an interesting layer of complexity to delineating their role in carbohydrate accumulation in the fruit.

4. The subcellular concentrations of metabolites and sugars should be estimated in order to determine potential changes in enzyme activity during development [79]. For example, Susy and fructokinase are inhibited by physiological levels of fructose [80]. Knowing the concentration of fructose in the cytosol may refine our view of how this enzyme works during fruit development.

5. Sugar signalling and sensing by invertase, hexokinases and as yet unidentified proteins should also be investigated. Invertases convert sucrose into hexoses, which in turn are used for carbon, energy and as signalling molecules and, by inference, are implicated in regulating all aspects of growth and development, including carbon partitioning to sinks [76, 81, 82]. The expression of each fruit invertase isoform - apoplastic, cytoplasmic and vacuolar - should be repressed individually and in combination. Zanor et al. used RNAi to silence LIN5, the apoplastic invertase in S. lycopersicum. Altered LIN5 is the basis for high TSS in $S$. pennellii. In so doing, they uncovered a web of interconnections between sugar content, and fruit development, fertility and importantly regulation of hormonal levels [25]. Hexokinases are sugar sensors and are central to sugar signalling in plants [83, 84]. Overexpression of Arabidopsis HK1 was performed using a constitutive promoter, which led to many developmental effects [22, 85, 86]. The consequence of overexpressing the native $\mathrm{HK}$ by using a fruit-specific promoter should also be pursued [17, 24].
6. Little is known about the regulation of substrate cycles of sucrose and starch in developing tomato fruit. Starch and sucrose levels are known to vary across cultivars and species and it seems reasonable to expect that these cycles may be regulated differently depending on genetic background. Transgenic manipulation of the degradation reaction may be one way to increase carbohydrate reserves [87].

7. Starch metabolism appears to help determine yield and/or TSS in some tomato cultivars and species. As previously mentioned, higher TSS in some wild tomatoes is associated with altered starch metabolism but now there is evidence to support this in cultivars, although changes in starch are not a universal path to high TSS. Dinar and Stevens made a link between young fruit starch content and fruit TSS and the results of other correlative studies support this [88, 89].

There is now evidence that starch plays a more direct role in determining TSS and yield. Two studies of transgenic lines whereby AGPase was overexpressed and suppressed, respectively, provided some clues. In the first study, an unregulated bacterial AGPase was transformed into tomato and this purportedly led to higher starch and increased TSS [90], but this report is controversial [87]. In another study, repression of the tomato AGPase activity by $90 \%$ apparently reduced starch to $25 \%$ of the levels found in wild-type and led to delayed flowering and lower yield. Although the results were tantalising in suggesting a relationship between starch and sink strength, as the authors noted, they could not rule out that the changes were due to somaclonal variation [91].

Second, it has long been observed that tomatoes subject to salt stress accumulate higher levels of starch in green fruit, and have elevated TSS in ripe fruit [45, 92, 93]. Initially, this was explained as a function of dilution effects, i.e., the high electrical conductivity meant the phloem supply to the fruit was more concentrated. Now, Yin et al. have provided direct proof that starch has a pivotal role since changes in salinity and osmotica altered AGPase at the transcriptional and posttranscriptional level, respectively, increasing green fruit starch 
biosynthesis [93]. As explained previously, partitioning of carbon to starch may increase sink strength in green fruit and then when it is degraded during ripening adds to the pool of sugars imported from the phloem [33, 34, 59].

Third, perhaps the best evidence for a role of starch in determining TSS in cultivars was found in transgenic tomatoes perturbed in malate content [94]. This set up cellular redox changes which altered the activation state of AGPase and, in turn, starch accumulation that was directly linked to modulation of fruit TSS [94]. Collectively these data point to an important role for starch metabolism in determining fruit carbon fluxes. There appear to be great differences in starch metabolism among cultivars [89] and there is evidence that granule degradation may be highly regulated [30]. It is intriguing, the possibility that flux in and out of starch could represent a core control point for tomato fruit metabolism.

\section{Conclusion}

Fruit traits are ultimately defined by a culmination of molecular events. With genomic resources readily accessible for tomato, comparative cross-species analyses of DNA, RNA, protein and metabolites within the Solanaceace is possible. Sugars along with hormones are powerful regulators of organ growth, development and metabolism, and these factors are often intertwined to determine the sugar-fruit size dynamic. However, as we are finding out, enzyme activities and biochemical flux analysis of high-TSS tomato species may still be indispensable in advancing our knowledge of the processes underlying fruit sugar accumulation.

\section{Acknowledgements}

We thank Drs. Nadia Bertin, Belinda Martineau, and the anonymous reviewers for their input on initial drafts of this manuscript. We also acknowledge Emily Kwok for help with editing. L. Stamova thanks
Mr. Chuck Rivara of the California Tomato Research Institute for use of greenhouse facilities; K. Luengwilai thanks the Anandamahidol Foundation for funding. DMB's work was supported by the Hatch Project \#: CA-D*-PLS-7821-H, the France Berkeley Fund and NSF-MCB-0620001.

\section{References}

[1] Giovannucci E., A review of epidemiologic studies of tomatoes, lycopene, and prostate cancer, Exp. Biol. Med. 227 (2002) 852-859.

[2] Giovannucci E., Lycopene and prostate cancer risk. Methodological considerations in the epidemiologic literature, Pure Appl. Chem. 74 (2002) 1427-1434.

[3] Giovannucci E., Rimm E.B., Liu Y., Stampfer M.J., Willett W.C., A, prospective study of tomato products, lycopene, and prostate cancer risk, J. Natl. Cancer Inst. 94 (2002) 391-398.

[4] Arab L., Steck S., Lycopene and cardiovascular disease, Am. J. Clin. Nutr. 71 (2000) 1691-1695.

[5] Sesso H.D., Liu S.M., Gaziano J.M., Buring J.E., Dietary lycopene, tomato-based food products and cardiovascular disease in women, J. Nutr. 133 (2003) 2336-2341.

[6] Boffetta P., Couto E., Wichmann J., Ferrari P., Trichopoulos D., Bueno-de-Mesquita H.B., van Duijnhoven F.J.B., Buchner F.L., Key T.,

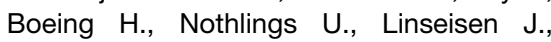
Gonzalez C.A., Overvad K., Nielsen M.R.S., Tjonneland A., Olsen A., Clavel-Chapelon F., Boutron-Ruault M.C., Morois S., Lagiou P., Naska A., Benetou V., Kaaks R., Rohrmann S., Panico S., Sieri S., Vineis P., Palli D., van Gils C.H., Peeters P.H., Lund E., Brustad M., Engeset D., Huerta J.M., Rodriguez L., Sanchez M.J., Dorronsoro M., Barricarte A., Hallmans G., Johansson I., Manjer J., Sonestedt E., Allen N.E., Bingham S., Khaw K.T., Slimani N., Jenab M., Mouw T., Norat T., Riboli E., Trichopoulou A., Fruit and vegetable intake and overall cancer risk in the European Prospective Investigation Into Cancer and Nutrition (EPIC), J. Natl. Cancer Inst. 102 (2010) 529-537.

[7] Jordan J., The Heirloom tomato as cultural object: investigating taste and space, Sociol. Rural. 47 (2007) 20-41. 
[8] Beckles D.M., Factors affecting the postharvest sugars and total soluble solids in tomato (Solanum lycopersicum L.) fruits, Postharvest Biol. Technol. 63 (2012) 129140.

[9] Stevens M.A., Inheritance of tomato quality components, in: J.J. (Ed.), Plant breeding reviews, AVI Publ. Co., Westport, Connecticut, U.S.A., 1986.

[10] Baldet P., Hernould M., Laporte F., Mounet F., Just D., Mouras A., Chevalier C., Rothan C., The expression of cell proliferation-related genes in early developing flowers is affected by a fruit load reduction in tomato plants, J. Exp. Bot. 57 (2006) 961-970.

[11] Ho L.C., Hewitt J.D., Fruit development, Chapman and Hall, N.Y., U.S.A., 1986.

[12] Mounet F., Moing A., Garcia V., Petit J., Maucourt M., Deborde C., Bernillon S., Le Gall G., Colquhoun I., Defernez M., Giraudel J.L., Rolin D., Rothan C., Lemaire-Chamley M., Gene and metabolite regulatory network analysis of early developing fruit tissues highlights new candidate genes for the control of tomato fruit composition and development, Plant Physiol. 149 (2009) 1505-1528.

[13] Wang H., Schauer N., Usadel B., Frasse P., Zouine M., Hernould M., Latche A., Pech J.C., Fernie A.R., Bouzayen M., Regulatory features underlying pollination-dependent and -independent tomato fruit set revealed by transcript and primary metabolite profiling, Plant Cell 21 (2009) 1428-1452.

[14] Gillaspy G., Bendavid H., Gruissem W., Fruits - a developmental perspective, Plant Cell 5 (1993) 1439-1451.

[15] Bohner J., Bangerth F., Cell number, cell size and hormone levels in semi-isogenic mutants of Lycopersicon pimpinellifolium differing in size, Physiol. Plant. 72 (1988) 316-320.

[16] Bertin N., Lecomte A., Brunel B., Fishman S. Genard M., A model describing cell polyploidization in tissues of growing fruit as related to cessation of cell proliferation, J. Exp. Bot. 58 (2007) 1903-1913.

[17] Klann E.M., Hall B., Bennett A.B., Antisense acid invertase (TIV1) gene alters soluble sugar composition and size in transgenic tomato fruit, Plant Physiol. 112 (1996) 13211330.
[18] Carrari F., Fernie A.R., Metabolic regulation underlying tomato fruit development, J. Exp. Bot. 57 (2006) 1883-1897.

[19] Cheniclet C., Rong W.Y., Causse M., Frangne N., Bolling L., Carde J.-P., Renaudin J.-P., Cell expansion and endoreduplication show a large genetic variability in pericarp and contribute strongly to tomato fruit growth, Plant Physiol. 139 (2005) 19841994.

[20] Chevalier C., Nafati M., Mathieu-Rivet E., Bourdon M., Frangne N., Cheniclet C., Renaudin J.P., Gevaudant F., Hernould M., Elucidating the functional role of endoreduplication in tomato fruit development, Ann. Bot. 107 (2011) 1159-1169.

[21] Prudent M., Causse M., Genard M., Tripodi P., Grandillo S., Bertin N., Genetic and physiological analysis of tomato fruit weight and composition: influence of carbon availability on QTL detection, J. Exp. Bot. 60 (2009) 923-937.

[22] Menu T., Saglio P., Granot D., Dai N., Raymond P., Ricard B., High hexokinase activity in tomato fruit perturbs carbon and energy metabolism and reduces fruit and seed size, Plant Cell Environ. 27 (2004) 89-98.

[23] Odanaka S., Bennett A.B., Kanayama Y., Distinct physiological roles of fructokinase isozymes revealed by gene-specific suppression of Frk1 and Frk2 expression in tomato, Plant Physiol. 129 (2002) 11191126.

[24] Ohyama A., Ito H., Sato T., Nishimura S., Imai T., Hirai M., Suppression of acid invertase activity by antisense RNA modifies the sugar composition of tomato fruit, Plant Cell Physiol. 36 (1995) 369-376.

[25] Zanor M.I., Osorio S., Nunes-Nesi A., Carrari F., Lohse M., Usadel B., Kuhn C., Bleiss W., Giavalisco P., Willmitzer L., Sulpice R., Zhou Y.H., Fernie A.R., RNA interference of LIN5 in tomato confirms its role in controlling Brix content, uncovers the influence of sugars on the levels of fruit hormones, and demonstrates the importance of sucrose cleavage for normal fruit development and fertility, Plant Physiol. 150 (2009) 1204-1218.

[26] Nesbitt T.C., Tanksley S.D., fw2.2 directly affects the size of developing tomato fruit, with secondary effects on fruit number and photosynthate distribution, Plant Physiol. 127 (2001) 575-583. 
[27] Nguyen-Quoc B., Foyer C.H., A role for 'futile cycles' involving invertase and sucrose synthase in sucrose metabolism of tomato fruit, J. Exp. Bot. 52 (2001) 881-889.

[28] Steinhauser M.C., Steinhauser D., Koehl K., Carrari F., Gibon Y., Fernie A.R., Stitt M., Enzyme activity profiles during fruit development in tomato cultivars and Solanum pennellii, Plant Physiol.153 (2010) 80-98.

[29] Yamaki S., Metabolism and accumulation of sugars translocated to fruit and their regulation, J. Jpn. Soc. Hortic. Sci. 79 (2010) 1-15.

[30] Luengwilai K., Beckles D.M., Starch granules in tomato fruit show a complex pattern of degradation, J. Agric. Food Chem. 57 (2009) 8480-8487.

[31] Wang F., Sanz A., Brenner M.L., Smith A., Sucrose synthase, starch accumulation, and tomato fruit sink strength, Plant Physiol. 101 (1993) 321-327.

[32] Bungerkibler S., Bangerth F., Relationship between cell number, cell-size and fruit size of seeded fruits of tomato (Lycopersicon esculentum Mill.), and those induced parthenocarpically by the application of plantgrowth regulators, Plant Growth Regul. 1 (1983) 143-154.

[33] Petreikov M., Yeselson L., Shen S., Levin I., Schaffer A.A., Efrati A., Bar M., Carbohydrate balance and accumulation during development of near-isogenic tomato lines differing in the AGPase-L1 allele, J. Am. Soc. Hortic. Sci. 134 (2009) 134-140.

[34] Guan H.P., Janes H.W., Light regulation of sink metabolism in tomato fruit .1. Growth and sugar accumulation, Plant Physiol. 96 (1991) 916-921.

[35] Yelle S., Hewitt J.D., Robinson N.L., Damon S., Bennett A.B., Sink metabolism in tomato fruit. 3. Analysis of carbohydrate assimilation in a wild-species, Plant Physiol. 87 (1988) 737-740.

[36] Obiadalla-Ali H., Fernie A.R., Lytovchenko A., Kossmann J., Lloyd J.R., Inhibition of chloroplastic fructose 1,6-bisphosphatase in tomato fruits leads to decreased fruit size, but only small changes in carbohydrate metabolism, Planta 219 (2004) 533-540.

[37] N'tchobo H., Dali N., Nguyen-Quoc B., Foyer C.H., Yelle S., Starch synthesis in tomato remains constant throughout fruit development and is dependent on sucrose supply and sucrose synthase activity, J. Exp. Bot. 50 (1999) 1457-1463.

[38] Robinson N.L., Hewitt J.D., Bennett A.B., Sink metabolism in tomato fruit. 1. Developmental-changes in carbohydrate metabolizing enzymes, Plant Physiol. 87 (1988) 727730.

[39] Beckles D.M., The subcellular location of ADPglucose pyrophosphorylase in starchstoring cells, Univ. Camb., Camb., U.K., 1998, $168 \mathrm{p}$.

[40] Cong B., Barrero L.S., Tanksley S.D., Regulatory change in YABBY-like transcription factor led to evolution of extreme fruit size during tomato domestication, Nat. Genet. 40 (2008) 800-804.

[41] Knapp S., Bohs L., Nee M., Spooner D.M., Solanaceae - a model for linking genomics with biodiversity, Comp. Funct. Genomics 5 (2004) 285-291.

[42] Agong S.G., Schittenhelm S., Friedt W., Assessment of tolerance to salt stress in Kenyan tomato germplasm, Euphytica 95 (1997) 57-66.

[43] Turhan A., Seniz V., Estimation of certain chemical constituents of fruits of selected tomato genotypes grown in Turkey, Afr. J. Agric. Res. 4 (2009) 1086-1092.

[44] Turhan A., Seniz V., Kuscu H., Genotypic variation in the response of tomato to salinity, Afr. J. Biotechnol. 8 (2009) 1062-1068.

[45] Balibrea M.E., Martinez-Andujar C., Cuartero J., Bolarin M.C., Perez-Alfocea F., The high fruit soluble sugar content in wild Lycopersicon species and their hybrids with cultivars depends on sucrose import during ripening rather than on sucrose metabolism, Funct. Plant Biol. 33 (2006) 279-288.

[46] Yelle S., Chetelat R.T., Dorais M., Deverna J.W., Bennett A.B., Sink metabolism in tomato fruit. 4. Genetic and biochemicalanalysis of sucrose accumulation, Plant Physiol. 95 (1991) 1026-1035.

[47] Baxter C.J., Carrari F., Bauke A., Overy S., Hill S.A., Quick P.W., Fernie A.R., Sweetlove L.J., Fruit carbohydrate metabolism in an introgression line of tomato with increased fruit soluble solids, Plant Cell Physiol. 46 (2005) 425-437.

[48] Miron D., Schaffer A.A., Sucrose phosphate synthase, sucrose synthase, and invertase activities in developing fruit of Lycopersicon esculentum Mill. and the sucrose accumulating Lycopersicon hirsutum Humb. and Bonpl., Plant Physiol 95 (1991) 623-627. 
[49] Stommel J.R., Enzymatic components of sucrose accumulation in the wild tomato species Lycopersicon peruvianum, Plant Physiol. 99 (1992) 324-328.

[50] Fridman E., Carrari F., Liu Y.S., Fernie A.R., Zamir D., Zooming in on a quantitative trait for tomato yield using interspecific introgressions, Science 305 (2004) 1786-1789.

[51] Klann E.M., Chetelat R.T., Bennett A.B., Expression of acid invertase gene controls sugar composition in tomato (Lycopersicon) fruit, Plant Physiol. 103 (1993) 863-870.

[52] Husain S.E., James C., Shields R., Foyer C.H., Manipulation of fruit sugar composition but not content in Lycopersicon esculentum fruit by introgression of an acid invertase gene from Lycopersicon pimpinellifolium, New Phytol. 150 (2001) 65-72.

[53] Husain S.E., Thomas B.J., Kingston-Smith A.H., Foyer C.H., Invertase protein, but not activity, is present throughout development of Lycopersicon esculentum and L. pimpinellifolium fruit, New Phytol. 150 (2001) 73-81.

[54] Levin I., Gilboa N., Cincarevsky F., Oguz I., Petreikov M., Yeselson Y., Shen S., Bar M., Schaffer A.A., Epistatic interaction between two unlinked loci derived from introgressions from Lycopersicon hirsutum further modulates the fructose-to-glucose ratio in the mature tomato fruit, Israel J. Plant Sci. 54 (2006) 215-222.

[55] Levin I., Gilboa N., Yeselson E., Shen S., Schaffer A.A., Fgr, a major locus that modulates the fructose to glucose ratio in mature tomato fruits, Theor. Appl. Genet. 100 (2000) 256-262.

[56] Schauer N., Zamir D., Fernie A.R., Metabolic profiling of leaves and fruit of wild species tomato: a survey of the Solanum lycopersicum complex, J. Exp. Bot. 56 (2005) 297307.

[57] Schaffer A.A., Levin I., Oguz I., Petreikov M., Cincarevsky F., Yeselson Y., Shen S., Gilboa N., Bar M., ADPglucose pyrophosphorylase activity and starch accumulation in immature tomato fruit: the effect of a Lycopersicon hirsutum-derived introgression encoding for the large subunit, Plant Sci. 152 (2000) 135144.

[58] Kortsee A.J., Appeldoorn N.J.G., Oortwijn M.E.P., Visser R.G.F., Differences in regulation of carbohydrate metabolism during early fruit development between domestica- ted tomato and two wild relatives, Planta 226 (2007) 929-939.

[59] Petreikov M., Shen S., Yeselson Y., Levin I., Bar M., Schaffer A.A., Temporally extended gene expression of the ADP-Glc pyrophosphorylase large subunit (AgpL1) leads to increased enzyme activity in developing tomato fruit, Planta 224 (2006) 1465-1479.

[60] Bertin N., Causse M., Brunel B., Tricon D., Genard M., Identification of growth processes involved in QTLs for tomato fruit size and composition, J. Exp. Bot. 60 (2009) 237248.

[61] Weber H., Heim U., Golombek S., Borisjuk L., Wobus U., Assimilate uptake and the regulation of seed development, Seed Sci. Res. 8 (1998) 331-345.

[62] Weber H., Borisjuk L., Wobus U., Sugar import and metabolism during seed development, Trends Plant Sci. 2 (1997) 169-174.

[63] Ohto M., Fischer R.L., Goldberg R.B., Nakamura K., Harada J.J., Control of seed mass by APETALA2, Proc. Natl. Acad. Sci. U.S.A. 102 (2005) 3123-3128.

[64] Yousef G.G., Juvik J.A., Evaluation of breeding utility of a chromosomal segment from Lycopersicon chmielewskii that enhances cultivated tomato soluble solids, Theor. Appl. Genet. 103 (2001) 1022-1027.

[65] Eshed Y., Zamir D., An introgression line population of Lycopersicon pennellii in the cultivated tomato enables the identification and fine mapping of yield-associated QTL, Genetics 141 (1995) 1147.

[66] Krieger U., Lippman Z.B., Zamir D., The flowering gene SINGLE FLOWER TRUSS drives heterosis for yield in tomato, Nat. Genet. 42 (2010) 459-463.

[67] Luengwilai K., Fiehn O.E., Beckles D.M., Comparison of leaf and fruit metabolism in two tomato (Solanum lycopersicum L.) genotypes varying in total soluble solids, J. Agric. Food Chem. 58 (2010) 11790-11800.

[68] Galiana-Balaguer L., Rosello S., Nuez F., Characterization and selection of balanced sources of variability for breeding tomato (Lycopersicon) internal quality, Genet. Res. Crop Evol. 53 (2006) 907-923.

[69] Rick C.M., High soluble solids content in large-fruited tomato lines derived from a wild green-fruited-species, Hilgardia 42 (1974) 493-510. 
[70] Stevens M.A., Kader A.A., Albrightholton M., Algazi M., Genotypic variation for flavor and composition in fresh market tomatoes, J. Am. Soc. Hortic. Sci. 102 (1977) 680-689.

[71] Grierson D., Kader A.A., Fruit ripening and quality, Chapman and Hall, Lond., U.K., 1986.

[72] Nookaraju A., Upadhyaya C.P., Pandey S.K., Young K.E., Hong S.J., Park S.K., Park S.W., Molecular approaches for enhancing sweetness in fruits and vegetables, Sci. Hortic. 127 (2010) 1-15.

[73] Stitt M., Sulpice R., Keurentjes J., Metabolic networks: How to identify key components in the regulation of metabolism and growth, Plant Physiol. 152 (2010) 428-444.

[74] Fernie A.R., Geigenberger P., Stitt M., Flux an important, but neglected, component of functional genomics, Curr. Opin. Plant Biol. 8 (2005) 174-182.

[75] Stitt M., The first will be last and the last will be first: non-regulated enzymes call the tune, BIOS Sci. Publ. Ltd., Oxf., U.K., 1999.

[76] Barratt D.H.P., Derbyshire P., Findlay K., Pike M., Wellner N., Lunn J., Feil R., Simpson C., Maule A.J., Smith A.M., Normal growth of Arabidopsis requires cytosolic invertase but not sucrose synthase, Proc. Natl. Acad. Sci. U.S.A. 106 (2009) 13124-13129.

[77] Weber A.P.M., Solute transporters as connecting elements between cytosol and plastid stroma, Curr. Opin. Plant Biol. 7 (2004) 247-253.

[78] Lecourieux F., Lecourieux D., Vignault C., Delrot S., A sugar-inducible protein kinase, VvSK1, regulates hexose transport and sugar accumulation in grapevine cells, Plant Physiol. 152 (2010) 1096-1106.

[79] Farre E.M., Fernie A.R., Willmitzer L., Analysis of subcellular metabolite levels of potato tubers (Solanum tuberosum) displaying alterations in cellular or extracellular sucrose metabolism, Metabolomics 4 (2008) 161170.

[80] Schaffer A.A., Petreikov M., Inhibition of fructokinase and sucrose synthase by cytosolic levels of fructose in young tomato fruit undergoing transient starch synthesis, Physiol. Plant. 101 (1997) 800-806.

[81] Roitsch T., Gonzalez M.C., Function and regulation of plant invertases: sweet sensations, Trends Plant Sci. 9 (2004) 606-613.
[82] Ruan Y.L., Jin Y., Yang Y.J., Li G.J., Boyer J.S., Sugar input, metabolism, and signaling mediated by invertase: roles in development, yield potential, and response to drought and heat, Mol. Plant 3 (2010) 942-955.

[83] Halford N.G., Purcell P.C., Hardie D.G., Is hexokinase really a sugar sensor in plants?, Trends Plant Sci. 4 (1999) 117-120.

[84] Rolland F., Baena-Gonzalez E., Sheen J., Sugar sensing and signalling in plants: Conserved and novel mechanisms, Annu. Rev. Plant Biol. 57 (2006) 675-709.

[85] Dai N., Schaffer A., Petreikov M., Shahak Y., Giller Y., Ratner K., Levine A., Granot D., Overexpression of Arabidopsis hexokinase in tomato plants inhibits growth, reduces photosynthesis, and induces rapid senescence, Plant Cell 11 (1999) 1253-1266.

[86] Roessner-TunaliU., HegemannB., Lytovchenko A., Carrari F., Bruedigam C., Granot D., Fernie A.R., Metabolic profiling of transgenic tomato plants overexpressing hexokinase reveals that the influence of hexose phosphorylation diminishes during fruit development, Plant Physiol. 133 (2003) 84-99.

[87] Smith A.M., Prospects for increasing starch and sucrose yields for bioethanol production, Plant J. 54 (2008) 546-558.

[88] Kortstee A.J., Appeldoorn N.J.G., Oortwijn M.E.P., Visser R.G.F., Differences in regulation of carbohydrate metabolism during early fruit development between domesticated tomato and two wild relatives, Planta 226 (2007) 929-939.

[89] Luengwilai K., Tananuwong K., Shoemaker C.F., Beckles D.M., Starch molecular structure shows little association with fruit physiology and starch metabolism in tomato, J. Agric. Food Chem. 58 (2010) 1275-1282.

[90] Stark D.M., Timmerman K.P., Barry G.F., Preiss J., Kishore G.M., Regulation of the amount of starch in plant-tissues by Adp glucose pyrophosphorylase, Science 258 (1992) 287-292.

[91] Obiadalla-Ali H., Understanding of carbon partitioning in tomato fruit, Max-Planck Inst. Mol. Plant Physiol., Golm, Ger., 2003.

[92] Gao Z.F., Sagi M., Lips S.H., Carbohydrate metabolism in leaves and assimilate partitioning in fruits of tomato (Lycopersicon esculentum L.) as affected by salinity, Plant Sci. 135 (1998) 149-159. 
[93] Yin Y.G., Kobayashi Y., Sanuki A., Kondo S., Fukuda N., Ezura H., Sugaya S., Matsukura C., Salinity induces carbohydrate accumulation and sugar-regulated starch biosynthetic genes in tomato (Solanum lycopersicum L. cv. 'Micro-Tom') fruits in an ABA- and osmotic stress-independent manner, J. Exp. Bot. 61 (2010) 563-574.

[94] Centeno D.C., Osorioa S., Nunes-Nesi A., Bertolo A.L.F., Carneiro R.T., Araújo W.L., Steinhauser M.-C., Michalska J., Rohrmann J., Geigenberger P., Olivera S.N., Stitt M., Carrari F., Rose J.K.C., Fernie A.R., Malate plays a crucial role in starch metabolism, ripening, and soluble solid content of tomato fruit and affects postharvest softening, Plant Cell 23 (2011) 162-184.

[95] Anon., United States standards for grades of fresh tomatoes, USDA, Wash. DC, U.S.A., 1991.

[96] Chetelat R.T., Deverna J.W., Bennett A.B., Effects of the Lycopersicon chmielewskii sucrose accumulator gene (Sucr) on fruit yield and quality parameters following introgression into tomato, Theor. Appl. Genet. 91 (1995) 334-339.

[97] Levin I., Lalazar A., Bar M., Schaffer A.A., Non GMO fruit factories strategies for modulating metabolic pathways in the tomato fruit, Ind. Crop. Prod. 20 (2004) 29-36.

[98] Clarke M., Carbohydrates, industrial, WileyVCH, N.Y., U.S.A., 1995.

[99] Luengwilai K., Sukjamsai K., Kader A.A., Responses of 'Clemenules Clementine' and 'W. Murcott' mandarins to low oxygen atmospheres, Postharvest Biol. Technol. 44 (2007) 48-54.
[100]Luengwilai K., Beckles D.M., Climacteric ethylene is not required for initiating chilling injury in tomato (Solanum lycopersicum L.), J. Stored Prod. Postharvest Res. 1 (2010) 1.

[101]D'Aoust M.A., Yelle S., Nguyen-Quoc B., Antisense inhibition of tomato fruit sucrose synthase decreases fruit setting and the sucrose unloading capacity of young fruit, Plant Cell 11 (1999) 2407-2418.

[102] Chengappa S., Guilleroux M., Phillips W., Shields R., Transgenic tomato plants with decreased sucrose synthase are unaltered in starch and sugar accumulation in the fruit, Plant Mol. Biol. 40 (1999) 213-221.

[103] Amemiya T., Kanayama Y., Yamaki S., Yamada K., Shiratake K., Fruit-specific VATPase suppression in antisense-transgenic tomato reduces fruit growth and seed formation, Planta 223 (2006) 1272-1280.

[104] Goren S., Huber S.C., Granot D., Comparison of a novel tomato sucrose synthase, SISUS4, with previously described SISUS isoforms reveals distinct sequence features and differential expression patterns in association with stem maturation, Planta 223 (2011) 1011-1023.

[105] Carrari F., Baxter C., Usadel B., UrbanczykWochniak E., Zanor M.-I., Nunes-Nesi A., Nikiforova V., Centeno D., Ratzka A., Pauly M., Sweetlove L.J., Fernie A.R., Integrated analysis of metabolite and transcript levels reveals the metabolic shifts that underlie tomato fruit development and highlight regulatory aspects of metabolic network behavior, Plant Physiol. 142 (2006) 1380-1396.

[106]Schaffer A.A., Petreikov M., Sucrose to starch metabolism in tomato fruit undergoing transient starch accumulation, Plant Physiol. 113 (1997) 739-746. 


\section{Factores bioquímicos que contribuyen al contenido de azúcar de los frutos de tomate: un repaso.}

Resumen - Introducción. Los consumidores e industriales aprecian los tomates con un fuerte índice de azúcares, pero la mayoría de las prácticas relativas al cultivo y de mejora tienen un impacto negativo sobre este rasgo característico. Las especies de tomate salvaje pueden acumular 2 ó 3 veces más azúcares en el fruto que los cultivares, y resultan ser apreciadas como fuente de loci de alto contenido en azúcares para aumentar la base genética de los cultivares actualmente producidos y como material de investigación para comprender dicho rasgo característico. Síntesis. A pesar de que los acercamientos genómicos punteros nos hayan enseñado mucho sobre el fenotipo de los frutos, sigue siendo importante evaluar la actividad de las encimas de los frutos, así como los flujos metabólicos en líneas que presenten situaciones contrastadas de acumulación de azúcares en los frutos. Dichas funciones metabólicas son las que más se acercan al rasgo característico del contenido de azúcares en el fruto maduro. En esta síntesis, nos centramos en las vías bioquímicas, particularmente en la biosíntesis del almidón, que puede influenciar los azúcares en el fruto del tomate. Intentamos, en la medida de lo posible, situar esta información en un contexto fisiológico, ya que, conjuntamente, influencian el rendimiento. Comparamos y contrastamos el metabolismo de los azúcares en los cultivares y en las especies salvajes de tomate, e identificamos los factores que pueden influenciar las diferencias en el tamaño de los frutos. Conclusión. A pesar de la dificultad, ilustramos la posibilidad de producir frutos que presenten un elevado rendimiento y utilizamos la línea seleccionada "Solara " como ejemplo. Además, sugerimos vías de investigación suplementarias para comprender la regulación y el control del contenido de glúcidos de los frutos.

EUA / Solanum lycopersicum / frutas / azucares / metabolismo de carbohidratos / contenido de carbohidratos 